\title{
ESTIMATING THE PROFITABILITY OF HYDROPOWER INVESTMENTS WITH A CASE STUDY FROM TURKEY
}

\author{
Emre Caner AKCAY ${ }^{\mathrm{a}}$, Irem DIKMEN ${ }^{\mathrm{b}}$, M. Talat BIRGONUL ${ }^{\mathrm{b}}$, David ARDITI ${ }^{\mathrm{a}}$ \\ ${ }^{a}$ Department of Civil, Architectural and Environmental Engineering, Illinois Institute of Technology, Alumni \\ Memorial Hall, 3201 S. Dearborn St., 60616, Chicago, USA \\ ${ }^{b}$ Department of Civil Engineering, Middle East Technical University, Dumlupinar Bulvart-1, 06800 Ankara, Turkey
}

Received 16 Mar 2017; accepted 29 Jun 2017

\begin{abstract}
Energy demand has been increasing, but traditional sources of energy are depletable. New investments are needed in renewable energy production. Hydroelectric power plants are often considered a feasible renewable source of energy and are often organized as a public private partnerships (PPP). However, risk factors stemming from the macro environment as well as project conditions should be considered in performing feasibility studies. The objective of this study was to develop a method that can be used to predict the profitability of hydropower investments considering the relevant risk factors. To that end, a cash flow that represents the construction and operation period is set up, the risk factors involved in such projects are identified, the impacts of these risk factors on the cash flow parameters are assessed, and Monte Carlo simulation is performed to estimate the net present value (NPV) of a hydropower investment. The proposed method was tested in a hydropower investment located in Turkey and generated credible results that could be of great benefit to potential investors operating in similar conditions. The primary contribution of this research is the creation of a method that allows investors to assess the profitability of a hydropower investment by using a stochastic approach.
\end{abstract}

Keywords: renewable energy, hydropower investment, Monte Carlo simulation, cash flow.

\section{Introduction}

Energy demand has been increasing all over the world as a consequence of rapidly increasing industrialization and population growth. According to the International Energy Agency (IEA 2007), the energy demand in the world increased by $48 \%$ between 1990 and 2010. IEA expects that this demand will further increase dramatically in the next 15 years.

The use of renewable sources of energy is considered in many countries to satisfy the increased energy demand. Turkey is one of these countries. As a result of rapid growth but limited traditional energy sources, more importance was attached to renewable energy in recent years in Turkey. However, like other developing countries, Turkey does not have enough funds to invest in large projects, and therefore uses public-private partnerships (PPPs) for constructing renewable energy power plants (Liu et al. 2014).

Public Private Partnerships are contractual agreements between a public agency and a private consortium for financing, designing, constructing, and operating large infrastructure facilities for a concession period (Shen et al. 2002; Zayed, Chang 2002). The PPP system is especially useful in developing countries where gov- ernments cannot finance large infrastructure projects due to lack of funds (Li, Akintoye 2008). At the end of the concession period, the private consortium transfers the facility to the public agency.

The PPP model was first introduced to Turkey in the early 1980s to solve an energy crisis (Ozdogan, Birgonul 2000). Since 2005, there have been 575 hydropower projects amounting to $\$ 6.5$ billion tendered on a PPP basis in Turkey. According to the targeted renewable power plant capacity that was announced by the Turkish government, it is estimated that hydroelectric power plants will produce a larger amount of energy compared to other renewable energy power plants by 2023 (RTMENR 2017).

This study focuses on hydropower projects carried out using the PPP model in Turkey. The trends in the Turkish energy market were observed and it was found that the feasibility studies performed by investors for hydroelectric power plants are far from realistic. The underlying idea of this paper is that in developing countries like Turkey, given the government's purchase guarantee of the generated electricity, hydropower projects can be profitable investment alternatives for investors, but risks should be analyzed and probabilistic assessments should

Corresponding author: Emre Caner Akcay

E-mail: eakcay@iit.edu 
be made considering the scenarios associated with the energy market. The objective of this study is to develop a method that can be used to predict the profitability of hydropower investments considering the risk factors associated with the energy market.

\section{Background research}

This research builds on and extends studies about (a) risk identification in PPP projects, and (b) methods for forecasting revenue and expenditure in PPP projects.

\subsection{Research on risk identification in PPP projects}

As more PPP projects are undertaken in several countries, the risk factors that affect PPP projects have been recently getting the attention of researchers. Several research studies have been conducted to identify the risk factors that affect different types of PPP projects in different countries (Chan et al. 2011; Shao et al. 2016; Wang et al. 2000; Ghorbani et al. 2014; Tang et al. 2015). While some research studies focus on the risk factors in the bargaining process between the public agency and the private consortium in PPP projects (e.g. Liu et al. 2016; Medda 2007; Shen et al. 2007), most other research studies focus on risk factors in PPP projects. For example, Shao et al. (2016) identified the risk factors for road PPP projects in China. They also determined the relative importance of each risk factor based on data collected in a questionnaire survey. On the other hand, Tang et al. (2015) explored the risk factors for PPP projects in Hong Kong and ranked the factors by their weighted importance. These and many other studies focus on critical risk factors in PPP projects by designing and administering questionnaire surveys to experts (Osei-Kyei, Chan 2015; Yuan et al. 2008; Wang et al. 2000). The research presented in this paper is complementary to these research studies, but differs from the existing studies in that it studies hydropower investments in Turkey.

\subsection{Research on methods for forecasting the revenue of PPP projects}

Revenue is an important parameter in PPP projects, as it impacts the decision of the private consortium to bid the job or not (Song et al. 2015). Research in forecasting the revenue of PPP projects can be divided into those that used (a) the net present value (NPV) method (e.g. Shen et al. 1996; Lee, Shen 1998; Malini 1999; Ye, Tiong 2000; Shen et al. 2002; Lianyu, Tiong 2005), or (b) simulation methods (e.g. Song et al. 2015; Zhang, Abourizk 2006; Ng et al. 2007; Liou, Huang 2008; Zayed, Chang 2002; Xing, Wu 2001). In the NPV method, the flow of income and costs are treated by a discount rate to find the present worth of the investment. It is to be noted that the NPV method is deterministic, i.e., ignores all uncertainties associated with the parameters of income, cost, discount rate, and life.

In contrast, in simulation methods, instead of certain values for cash flow parameters, probability distributions are assigned to each parameter. For example, Shen and Wu (2005) developed such a model to estimate the NPV of toll bridges undertaken by PPP.

The research presented in this work builds on this foundation and focuses on identifying the probability distribution of each cash flow parameter in hydropower investments by considering the relevant risk factors. Although quite a few researchers used simulation methods for PPP projects, not one focused on hydropower projects. The need persists to identify the risk factors that are critical in determining the NPV of hydropower projects undertaken by PPP.

\section{Proposed method to determine the NPV of hydropower investments}

The proposed method to determine the NPV of hydropower investments is performed in four steps: (1) identifying of the cash flow parameters for hydropower investments, (2) identifying of the risk factors and their impact on hydropower investments, (3) setting up a probability distribution for each cash flow parameter, and (4) performing Monte Carlo simulation to calculate the expected NPV of hydropower investments.

\subsection{Identification of the cash flow parameters of hydropower investments}

In order to evaluate a project, the net present value (NPV) of the cash flow needs to be calculated (Zhang 2005). The NPV of the cash flow is the actual profit/loss of the project and is found by carrying all the cost and income items to the starting point of the cash flow (Liou, Huang 2008). The first step of the proposed method is to identify the parameters that affect hydropower investments such that the analyst can set up a cash flow diagram. This process was performed by examining more than 30 feasibility reports prepared for 30 hydropower investments in Turkey. According to these feasibility reports, the cash flow is composed of costs and incomes, a discount rate, and the length of the concession period. The income of the investor involves revenue from sales and is calculated by multiplying the unit price of energy by the amount of energy sold, which in turn depends on the installed power and the demand. The initial costs incurred by the investor include the cost of expropriation, excavation, construction, turbines and generator, transmission lines, and penstock, whereas the annual costs involve operation and maintenance costs. In addition to these costs and incomes, an interest rate and concession period are used to carry all the costs and incomes to the starting point of the cash flow in order to find the NPV.

\subsection{Risk factors and their impact on hydroelectric power plant projects}

There are various definitions of risk in the literature. PMBOK (2011) defines risk as "an uncertain event or condition that, if it occurs, has a positive or negative effect on at least one project objective such as time, cost, 
span or quality". Smith (1999) describes risk as "a decision expressed by a range of possible outcomes with attached probabilities". Al-Bahar and Crandall (1990) explain risk as "the exposure to the chance of occurrences of events adversely or favorably affecting project objectives as a consequence of uncertainty". In current practice, the cashflow parameters are determined by using "best estimates" considering the most likely scenario, because it is difficult to estimate the uncertainties associated with these parameters (Ye, Tiong 2000). However, in real life, there are risk factors and various possible scenarios that may affect the values of the parameters and consequently the results. The second step of the proposed method involves identifying the risk factors and their impact on hydropower investments. For this purpose, the risk factors that affect the cash flow parameters were determined by means of an extensive literature survey. The risk factors so identified are presented in Table 1.

Table 1. External and technical risk factors for hydropower investments

\begin{tabular}{|c|c|c|c|c|c|c|c|c|c|c|c|c|c|c|c|c|}
\hline RISK FACTORS & 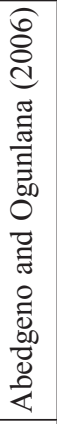 & 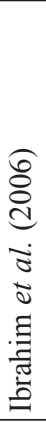 & 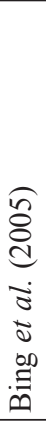 & 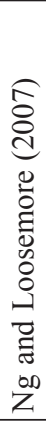 & 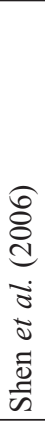 & 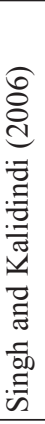 & 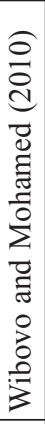 & 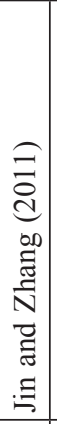 & 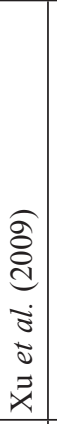 & 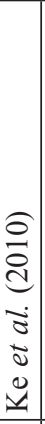 & 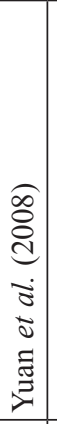 & 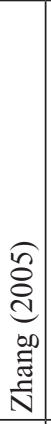 & 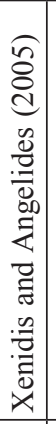 & 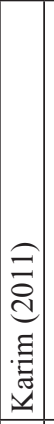 & 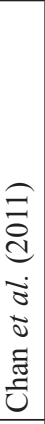 & 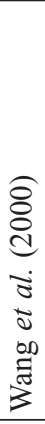 \\
\hline \multicolumn{17}{|l|}{ EXTERNAL RISK FACTORS } \\
\hline Change in law & & $\mathrm{x}$ & $\mathrm{x}$ & $\mathrm{x}$ & & $\mathrm{x}$ & $\mathrm{x}$ & & $\mathrm{x}$ & $\mathrm{x}$ & $\mathrm{x}$ & $\mathrm{x}$ & & $\mathrm{x}$ & $\mathrm{x}$ & $\mathrm{x}$ \\
\hline Delay in project approvals and permits & $\mathrm{x}$ & $\mathrm{x}$ & $\mathrm{x}$ & & & $\mathrm{x}$ & & $\mathrm{x}$ & $\mathrm{x}$ & $\mathrm{x}$ & $\mathrm{x}$ & & & $\mathrm{x}$ & $\mathrm{x}$ & $\mathrm{x}$ \\
\hline Change in government & $\mathrm{x}$ & $\mathrm{x}$ & $\mathrm{x}$ & $\mathrm{x}$ & $\mathrm{x}$ & $\mathrm{x}$ & $\mathrm{x}$ & & $\mathrm{x}$ & $\mathrm{x}$ & & & & $\mathrm{x}$ & $\mathrm{x}$ & $\mathrm{x}$ \\
\hline Unavailability in material during construction & & $\mathrm{x}$ & $\mathrm{x}$ & $\mathrm{x}$ & & & & $\mathrm{x}$ & $\mathrm{x}$ & $\mathrm{x}$ & $\mathrm{x}$ & $\mathrm{x}$ & & $\mathrm{x}$ & $\mathrm{x}$ & \\
\hline Unavailability of labour hours & $\mathrm{x}$ & $\mathrm{x}$ & $\mathrm{x}$ & & $\mathrm{x}$ & & & & $\mathrm{x}$ & $\mathrm{x}$ & & & & $\mathrm{x}$ & $\mathrm{x}$ & \\
\hline Unavailability of finance & $\mathrm{x}$ & $\mathrm{x}$ & $\mathrm{x}$ & & $\mathrm{x}$ & & & & $\mathrm{x}$ & $\mathrm{x}$ & & & & $\mathrm{x}$ & $\mathrm{x}$ & \\
\hline Insolvency of subcontractors and suppliers & $\mathrm{x}$ & $\mathrm{x}$ & $\mathrm{x}$ & & & & & $\mathrm{x}$ & $\mathrm{x}$ & $\mathrm{x}$ & $\mathrm{x}$ & & $\mathrm{x}$ & $\mathrm{x}$ & & \\
\hline Change in tax regulations & & $\mathrm{x}$ & $\mathrm{x}$ & $\mathrm{x}$ & & $\mathrm{x}$ & $\mathrm{x}$ & & $\mathrm{x}$ & & & & & $\mathrm{x}$ & $\mathrm{x}$ & $\mathrm{x}$ \\
\hline Import restrictions & & $\mathrm{x}$ & & & & & & & & & & & $\mathrm{x}$ & $\mathrm{x}$ & & \\
\hline Inflation rate volatility & & $\mathrm{x}$ & $\mathrm{x}$ & $\mathrm{x}$ & $\mathrm{x}$ & $\mathrm{x}$ & & & $\mathrm{x}$ & $\mathrm{x}$ & & $\mathrm{x}$ & $\mathrm{x}$ & $\mathrm{x}$ & $\mathrm{x}$ & $\mathrm{x}$ \\
\hline Fluctation in foreign exchange rates and inconvertibility & & $\mathrm{x}$ & $\mathrm{x}$ & & $\mathrm{x}$ & $\mathrm{x}$ & & & $\mathrm{x}$ & $\mathrm{x}$ & $\mathrm{x}$ & $\mathrm{x}$ & $\mathrm{x}$ & $\mathrm{x}$ & $\mathrm{x}$ & $\mathrm{x}$ \\
\hline Adverse change in financial markets & $\mathrm{x}$ & $\mathrm{x}$ & $\mathrm{x}$ & $\mathrm{x}$ & $\mathrm{x}$ & $\mathrm{x}$ & $\mathrm{x}$ & $\mathrm{x}$ & & $\mathrm{x}$ & & $\mathrm{x}$ & $\mathrm{x}$ & $\mathrm{x}$ & $\mathrm{x}$ & \\
\hline Fluctation in tariff rates specified by government & & $\mathrm{x}$ & $\mathrm{x}$ & $\mathrm{x}$ & $\mathrm{x}$ & & $\mathrm{x}$ & & & $\mathrm{x}$ & $\mathrm{x}$ & $\mathrm{x}$ & & $\mathrm{x}$ & $\mathrm{x}$ & $\mathrm{x}$ \\
\hline Fluctation in energy demand & & & $\mathrm{x}$ & $\mathrm{x}$ & $\mathrm{x}$ & & & & $\mathrm{x}$ & $\mathrm{x}$ & & $\mathrm{x}$ & $\mathrm{x}$ & $\mathrm{x}$ & $\mathrm{x}$ & $\mathrm{x}$ \\
\hline Public opposition to project & & $\mathrm{x}$ & $\mathrm{x}$ & & & & & & $\mathrm{x}$ & & $\mathrm{x}$ & $\mathrm{x}$ & & $\mathrm{x}$ & $\mathrm{x}$ & \\
\hline Change in interest rates & $\mathrm{x}$ & $\mathrm{x}$ & $\mathrm{x}$ & $\mathrm{x}$ & & $\mathrm{x}$ & $\mathrm{x}$ & & & $\mathrm{x}$ & & & & $\mathrm{x}$ & $\mathrm{x}$ & $\mathrm{x}$ \\
\hline Force majeure & $\mathrm{x}$ & $\mathrm{x}$ & $\mathrm{x}$ & $\mathrm{x}$ & $\mathrm{x}$ & $\mathrm{x}$ & $\mathrm{x}$ & & $\mathrm{x}$ & $\mathrm{x}$ & $\mathrm{x}$ & & & $\mathrm{x}$ & $\mathrm{x}$ & $\mathrm{x}$ \\
\hline Unaforable weather conditions during construction & $\mathrm{x}$ & $\mathrm{x}$ & $\mathrm{x}$ & & $\mathrm{x}$ & & & & $\mathrm{x}$ & $\mathrm{x}$ & $\mathrm{x}$ & & & $\mathrm{x}$ & $\mathrm{x}$ & \\
\hline Low flow rate during the operation period & & $\mathrm{x}$ & $\mathrm{x}$ & & $\mathrm{x}$ & & & & & $\mathrm{x}$ & & & & $\mathrm{x}$ & & \\
\hline \multicolumn{17}{|l|}{ TECHNICAL RISK FACTORS } \\
\hline Problems with design & $\mathrm{x}$ & $\mathrm{x}$ & $\mathrm{x}$ & $\mathrm{x}$ & $\mathrm{x}$ & & & & & $\mathrm{x}$ & $\mathrm{x}$ & & & $\mathrm{x}$ & & \\
\hline Delay in construction & $\mathrm{x}$ & $\mathrm{x}$ & $\mathrm{x}$ & $\mathrm{x}$ & $\mathrm{x}$ & $\mathrm{x}$ & $\mathrm{x}$ & & & $\mathrm{x}$ & $\mathrm{x}$ & $\mathrm{x}$ & & $\mathrm{x}$ & & $\mathrm{x}$ \\
\hline Vagueness of geotechnical conditions & $\mathrm{x}$ & & $\mathrm{x}$ & $\mathrm{x}$ & $\mathrm{x}$ & $\mathrm{x}$ & & & $\mathrm{x}$ & $\mathrm{x}$ & & & & $\mathrm{x}$ & $\mathrm{x}$ & \\
\hline Poor quality of construction (rework) & $\mathrm{x}$ & $\mathrm{x}$ & $\mathrm{x}$ & & $\mathrm{x}$ & & & & & $\mathrm{x}$ & $\mathrm{x}$ & & & $\mathrm{x}$ & & $\mathrm{x}$ \\
\hline Change in scope (increase/decrease in quantities) & $\mathrm{x}$ & $\mathrm{x}$ & $\mathrm{x}$ & $\mathrm{x}$ & $\mathrm{x}$ & & & & & $\mathrm{x}$ & & $\mathrm{x}$ & & $\mathrm{x}$ & & \\
\hline Technical problems during operation & & $\mathrm{x}$ & $\mathrm{x}$ & & & $\mathrm{x}$ & $\mathrm{x}$ & $\mathrm{x}$ & & $\mathrm{x}$ & $\mathrm{x}$ & & & $\mathrm{x}$ & & $\mathrm{x}$ \\
\hline Technical problems during construction & $\mathrm{x}$ & $\mathrm{x}$ & $\mathrm{x}$ & & $\mathrm{x}$ & $\mathrm{x}$ & $\mathrm{x}$ & $\mathrm{x}$ & & $\mathrm{x}$ & $\mathrm{x}$ & & & $\mathrm{x}$ & & $\mathrm{x}$ \\
\hline Lack of organization and coordination & & $\mathrm{x}$ & $\mathrm{x}$ & $\mathrm{x}$ & $\mathrm{x}$ & $\mathrm{x}$ & $\mathrm{x}$ & & $\mathrm{x}$ & $\mathrm{x}$ & & $\mathrm{x}$ & & & $\mathrm{x}$ & \\
\hline Third party delays (suppliers, subcontractors, etc.) & & $\mathrm{x}$ & $\mathrm{x}$ & $\mathrm{x}$ & $\mathrm{x}$ & & $\mathrm{x}$ & & $\mathrm{x}$ & $\mathrm{x}$ & & & & $\mathrm{x}$ & $\mathrm{x}$ & \\
\hline Accidents & & $\mathrm{x}$ & $\mathrm{x}$ & & $\mathrm{x}$ & & & & & $\mathrm{x}$ & & & & $\mathrm{x}$ & & \\
\hline
\end{tabular}


A questionnaire survey was conducted to identify the impact of the risk factors on the cash flow parameters. A total of 50 experts were chosen at random from the member companies of the Turkish Contractors Association that have hydropower investments in at least one of Turkey's seven regions. The association represents the leading construction companies in Turkey and the business volume of its members amounts to almost $70 \%$ of all domestic and $90 \%$ of all international contracting work performed by Turkish construction companies (TCA 2016). All experts had been involved in hydropower projects for more than 20 years.

Before the survey, the respondents were asked to review the risk factors and see if they want to adjust some of the factors and/or to add new factors. The list was found to be satisfactory and no revisions were suggested. Respondents were asked to rate the impact of each risk factor on each cash flow parameter on a four-point scale, where " 0 " indicates no impact, " 1 " low impact, " 2 " moderate impact, and " 3 " high impact.

The Delphi Method was used to minimize the differences between respondents. The questionnaire was administered to the experts twice. After the first round, the experts' answers were made available to all the experts, and they were asked to revise their earlier answers in the light of the other experts' answers. This way, the spread of the answers (measured by the standard deviation) was minimized, and a degree of consensus was reached. The modes of the distributions of the responses are presented in Table 2.

Some of the cash flow parameters were consolidated and renamed for convenience. For example: instead of considering the costs of weirs, turbines and generator, penstock, transmission lines, excavation, and superstructure separately, only "cost of construction" was used as a single parameter that represents the sum of all these parameters. Similarly, the risk factor "T1 - Problems with design" includes uncertainties and variations associated with various technical parameters that have to be considered during design such as the capacity of the reservoir, dimensions of the dam, and type of the turbine.

\subsection{Identification of the probability distribution of each cash flow parameter}

The main reason for determining the risk factors and their impact on cash flow parameters is to establish a realistic probability distribution for each cash flow parameter, hence aiming for more realistic predictions for the profitability of hydropower investments. In order to determine the nature of the probability distributions for the cash flow parameters, a face-to-face meeting was arranged with 20 experts who were a subset of the 50 experts who participated in the earlier questionnaire survey. By taking into consideration the risk factors and their impact on cash flow parameters (Table 2), and with the help of their knowledge and experiences related to hydropower investments, the experts identified the best, most likely, and worst case scenarios, as well as the probability distribution for each cash flow parameter (Table 3). For example, according to the experts, the best case scenario for project duration is $10 \%$ earlier than the planned duration, whereas in the worst case scenario, the project would be finished $200 \%$ later than the planned duration. The respondents also agreed unanimously that a triangular distribution represents the reality well for all cash flow parameters. Pouliquen (1970) recommends that, in the Monte Carlo simulation, the results depend on choice of occurence ranges rather than shape of probability distributions. Thus, if a normal or trapezoidal distribution were chosen instead of triangular distribution within the same occurence range, the results would only change marginally.

In addition, correlations were defined to show the dependencies between cash flow parameters by seeking the subjective assessments of experts as recommended by Beeston (1986). If the cash flow parameters are affected from similar risk factors, then the correlation between them is determined as "strong". Thus, while identifying the correlations, the vulnerability of cash flow parameters to various risk factors is considered as well as the direction of relationship (positive or negative), as identified by the experts. For instance, the strong inverse relationship between energy production and selling price, that was identified by the experts translated into a correlation coefficient of -1 . This and other correlation coefficients are reflected in @ Risk.

After finding the probability distribution of each cash flow parameter, Monte Carlo Simulation was performed to calculate the expected profitability by performing net present value (NPV) analysis using the probability distributions of the cash flow parameters given in Table 3 .

\subsection{Monte Carlo simulation of hydropower investments}

Monte Carlo simulation is a technique that helps solve mathematical and statistical problems that are too complicated to solve analytically. It is widely used in energy, finance, project management, engineering, insurance, transportation, and manufacturing.

The mathematical model for the feasibility of hydropower investment was created by converting the cash flow diagram into a mathematical formulation that can receive a range of values for each parameter according to its probability distribution. In Monte Carlo simulation, different combinations of different values of different variables are considered. Possible outcomes for each combination are calculated. The simulation runs many cycles depending upon the number and distribution of variables. At the end, the cumulative probability distribution of possible outcomes and a tornado diagram of the variables are obtained (Flanagan, Norman 1993).

The common Monte Carlo simulation software programs that are add-ins to Microsoft Excel include RiskAMP, SimVoi, Oracle Crystal Ball, Monte Carlito, 


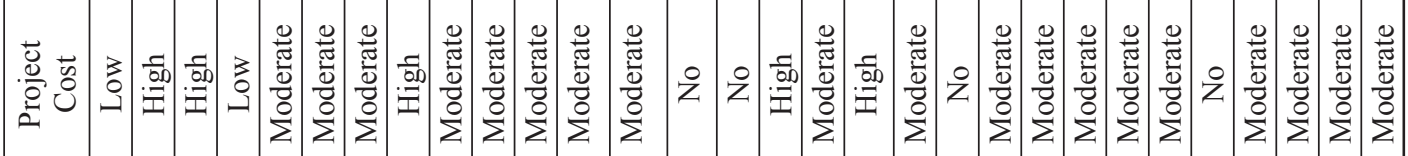

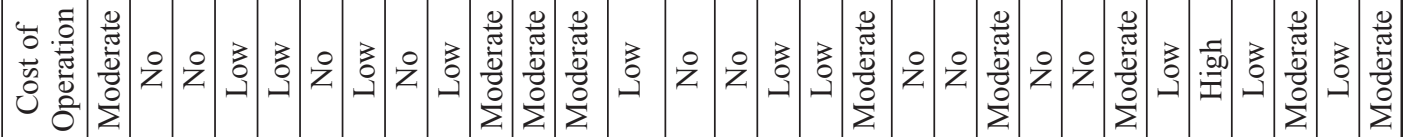

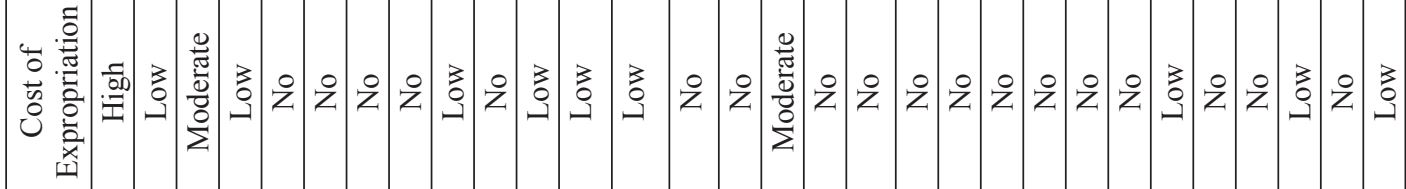
(1)

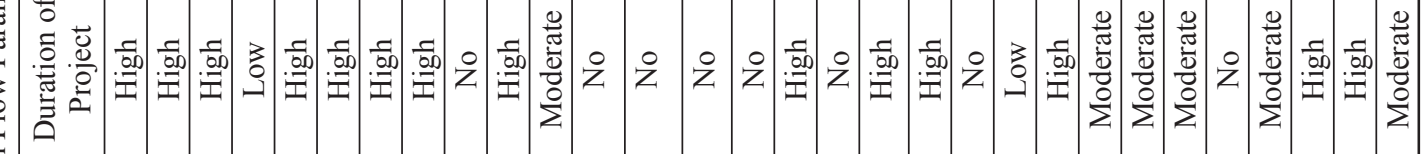
离

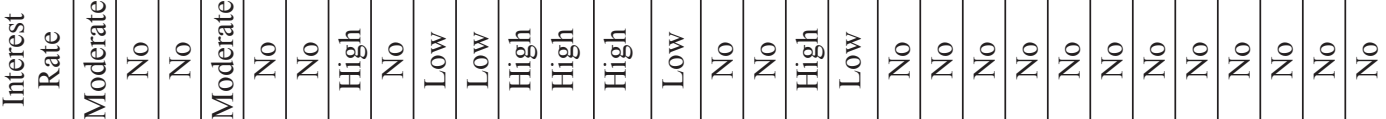

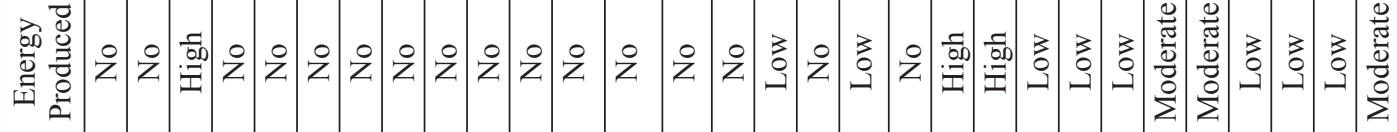

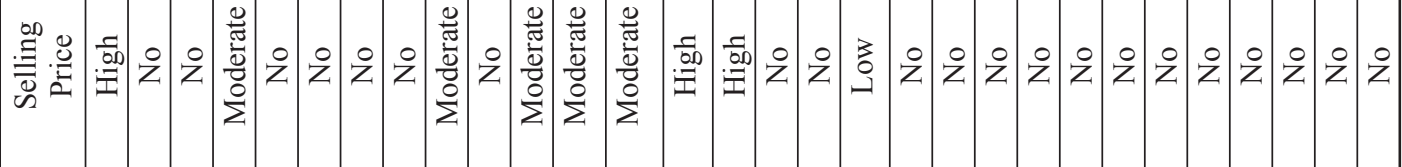

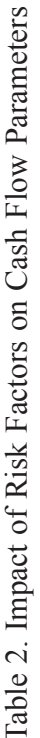

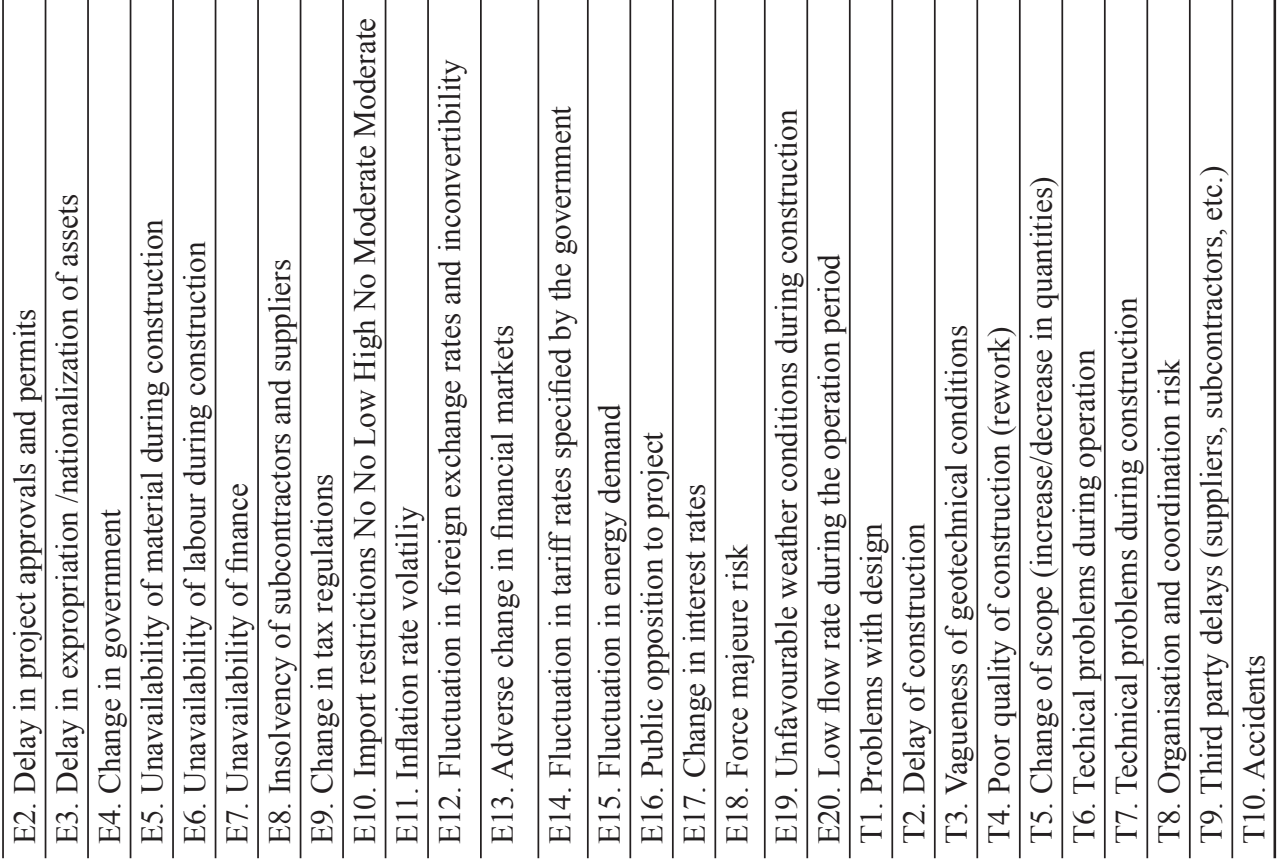


Table 3. Probability distributions for cash flow elements

\begin{tabular}{lccc}
\hline \multicolumn{1}{c}{ Cash Flow Parameters } & Best Case Scenario & Most Likely Scenario & Worst Case Scenario \\
\hline Duration of construction & $0.9 \times \mathrm{D}$ & $\mathrm{D}$ & $3 \times \mathrm{D}$ \\
\hline Cost of construction & $0.93 \times \mathrm{C}_{\mathrm{C}}$ & $\mathrm{C}_{\mathrm{C}}$ & $1.5 \times \mathrm{C}_{\mathrm{C}}$ \\
\hline Cost of expropriation & $0.85 \times \mathrm{C}_{\mathrm{E}}$ & $\mathrm{C}_{\mathrm{E}}$ & $1.4 \times \mathrm{C}_{\mathrm{E}}$ \\
\hline Amount of produced energy & $1.25 \times \mathrm{E}$ & $\mathrm{E}$ & $0.75 \times \mathrm{E}$ \\
\hline Cost of operation and maintenance & $0.8 \times \mathrm{C}_{\mathrm{O}}$ & $\mathrm{C}_{\mathrm{O}}$ & $1.5 \times \mathrm{C}_{\mathrm{O}}$ \\
\hline Interest rate & $0.63 \times \mathrm{i}$ & $\mathrm{i}$ & $1.47 \times \mathrm{i}$ \\
\hline Selling price of energy & $3.34 \times \mathrm{P}$ & $\mathrm{P}$ & $\mathrm{P}$ \\
\hline
\end{tabular}

Table 4. Probability distributions for cash flow elements for case study

\begin{tabular}{lccc}
\hline \multicolumn{1}{c}{ Cash Flow Parameters } & Best Case Scenario & Most Likely Scenario & Worst Case Scenario \\
\hline Duration of construction & $0.9 \times \mathrm{D}=0.9$ year & $\mathrm{D}=1$ year & $3 \times \mathrm{D}=3$ years \\
\hline Cost of construction & $0.93 \times \mathrm{C}_{\mathrm{C}}=\$ 18,662,403$ & $\mathrm{C}_{\mathrm{C}}=\$ 20,067,100$ & $1.5 \times \mathrm{C}_{\mathrm{C}}=\$ 30,100,650$ \\
\hline Cost of expropriation & $0.85 \times \mathrm{C}_{\mathrm{E}}=\$ 255,000$ & $\mathrm{C}_{\mathrm{E}}=\$ 300,000$ & $1.4 \times \mathrm{C}_{\mathrm{E}}=\$ 420,000$ \\
\hline Amount of produced energy & $1.25 \times \mathrm{E}=112,500,000 \mathrm{~kW} . \mathrm{h}$ & $\mathrm{E}=90,000,000 \mathrm{~kW} . \mathrm{h}$ & $0.75 \times \mathrm{E}=67,500,000 \mathrm{~kW} . \mathrm{h}$ \\
\hline Cost of operation and maintenance & $0.8 \times \mathrm{C}_{\mathrm{O}}=\$ 268,800$ & $\mathrm{C}_{\mathrm{O}}=\$ 336,000$ & $1.5 \times \mathrm{C}_{\mathrm{O}}=\$ 504,000$ \\
\hline Interest rate & $0.63 \times \mathrm{i}=6 \%$ & $\mathrm{i}=9.5 \%$ & $1.47 \times \mathrm{i}=14 \%$ \\
\hline Selling price of energy & $3.34 \times \mathrm{P}=20 \phi / \mathrm{kWh}$ & $\mathrm{P}=6 \varnothing / \mathrm{kWh}$ & $\mathrm{P}=6 \notin / \mathrm{kWh}$ \\
\hline
\end{tabular}

Palisade's@Risk, and Simulator. As it is extensively used and easy to use, Palisade's@Risk software was used in this research.

\section{Case study}

A small hydropower investment in Turkey that was built in four successive stages, each of which added 7.5 MW capacity was used as a case study. According to the prefeasibility report, this hydropower plant will work 3,000 hours per year. The risk factors and their impact on the cash flow parameter are presented in Table 2. The best, most likely, and worst case values of the cash flow parameters are presented in Table 4 . The cash flow diagram for the deterministic approach using the most likely scenario for all cash flow parameter is shown in Figure 1. According to the cash flow analysis, the net present value (NPV) was found to be $\$ 27,845,377$, clearly a profitable venture.

For stochastic analysis, the triangular probability distributions of the parameters were entered into the model, and Monte Carlo simulation was performed. The resulting probability distribution for the NPV is shown in Figure 2, according to which the NPV for the best case scenario is $\$ 188,813,602$, whereas, the NPV for the worst case scenario is $-\$ 2,641,704$. The expected NPV is $\$ 56,433,578$. According to Figure 2, there is only $13.5 \%$ probability that the deterministic NPV of $\$ 27,845,377$ will be less than the expected NPV of $\$ 56,433,578$.

Monte Carlo simulation also produces a tornado diagram presented in Figure 3. This graph is an output of comparative sensitivity analysis for input variables. According to this tornado diagram, the relationships be- tween NPV and selling price of energy and between NPV and amount of energy produced are positive, whereas relationships with the interest rate, the duration of construction, the cost of construction, operation and expropriation are negative. The directions of the relationships make sense since the NPV is expected to be higher if unit selling price and amount of energy sold are high. Similarly the NPV is expected to go down when the interest rate is higher (because the uniform series present worth factor goes down as the interest rate goes up), when the duration of construction is longer (because the operation period is shorter when construction takes longer), when the cost of expropriation + construction + operation goes up.

The tornado graph also informs which parameters are important in the calculation of the NPV. A wide bar can cause a big change in the objective function (Syncopation 2017). According to Figure 3, the most influential parameter when determining the NPV is the selling price of energy. As seen in Table 2, the selling price of energy heavily depends on changes in tariff rates made by the government, changes in laws, and fluctuations in energy demand. The first two risk factors (changes in tariffs and changes in laws) depend on the stability of governmental policies about renewable energy. It is safe to assume that if this research had been performed in an industrialized country such as the U.S., these risk factors would not have had as much importance as they do in a developing country such as Turkey. In advanced countries, the renewable energy discussion is not new, and the regulations and tariff rates are already established, whereas in developing countries, the laws and tariff rates related to renewable energy have not yet settled down (Akcay 


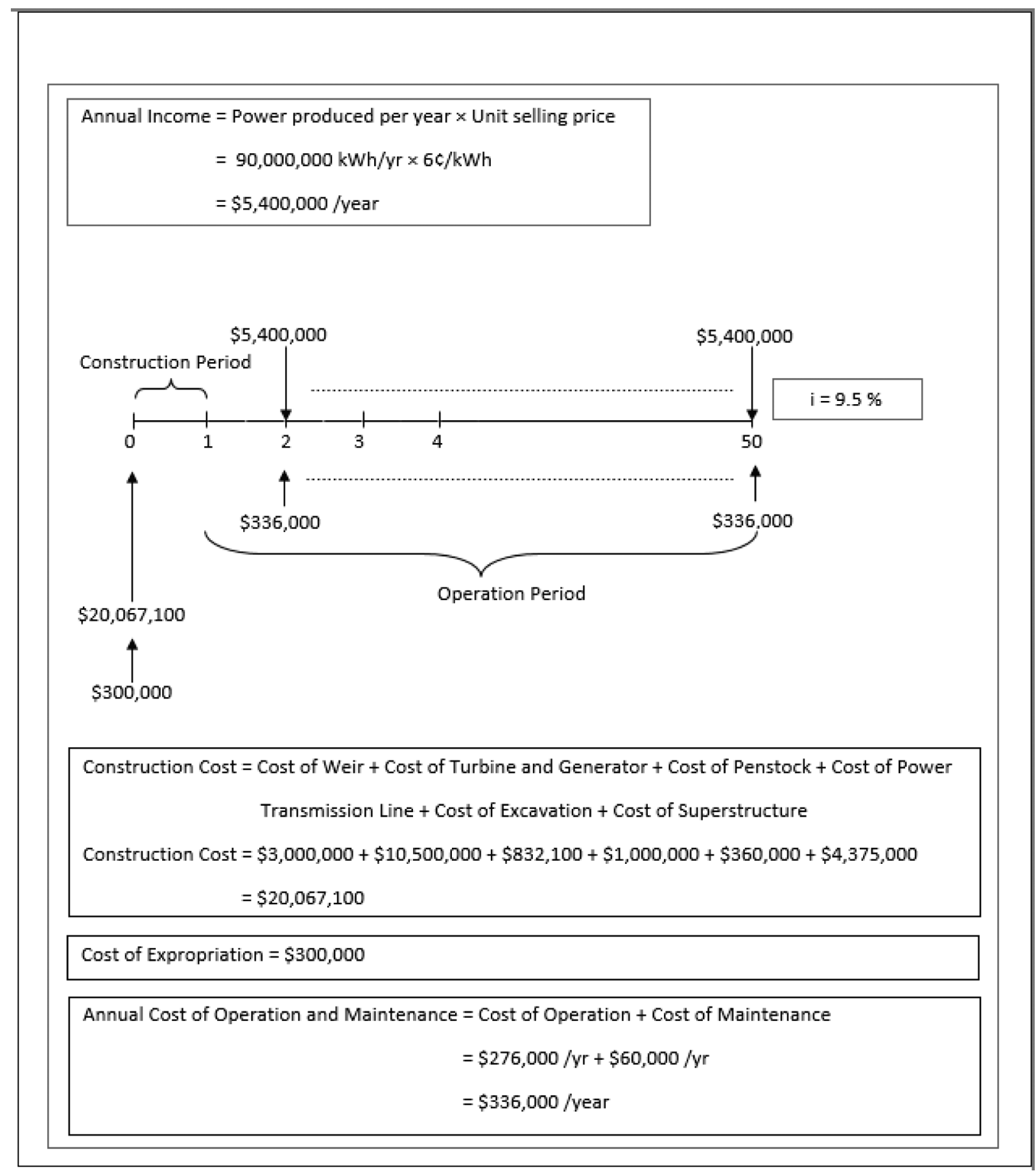

Fig. 1. Deterministic cash flow diagram for the case study

2014), inevitably leading to changes in laws and tariff rates, which in turn results in fluctuations in the selling price of energy.

According to the tornado graph, the second most influential parameter is interest rate. Generally, the longer the life of an investment, the more sensitive the NPV to changes in interest rate (Blank, Tarquin 2012). Since concession periods in hydroelectric power plant projects undertaken by PPP are often 50 years in Turkey, it is not surprising that the interest rate is a dominant factor in the calculation of NPV. The interest rate is directly related to the economic condition of the country where the investment is made. So instead of using only the interest rate specified by the Central Bank at the time the project was undertaken, it is more realistic to use the probability distribution of the interest rate determined according to the risk factors identified by experts.

The third most influential parameter is the amount of energy produced. Although there are several factors that affect this parameter, flow rate and the technology used in the power plant are the most important factors (Akcay 2014). The flow rate depends on upstream weather 


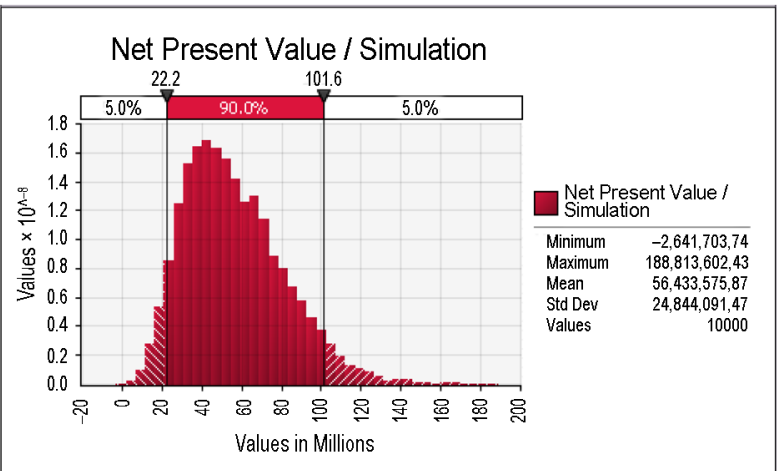

Fig. 2. Probability distribution for Net present value

conditions and is out of the investor's control, but the technology of the power plant depends on the investor's preference. As James (2013) states the energy produced can be increased by up to $85 \%$ by choosing the right technology, hence dramatically increasing the revenue of an investment.

The differences between the NPVs of the deterministic and stochastic models can be explained by the selling price of energy. In the deterministic model, the guaranteed price given by the government is traditionally assumed to be the selling price of energy, whereas in reality, this guaranteed price is actually the worst case scenario for investors. So using a reasonable distribution instead of using the worst case scenario for the most important parameter increases the NPV significantly. In addition, experts stated that using a "single" selling price of energy in feasibility studies is unrealistic as selling price varies depending on various conditions such as changes in laws, and changes in financial markets. The experts also stated that using a probability distribution for the selling price of the energy is more realistic than using a single deterministic value. However, it is important to note that, depending on the circumstances in the energy market, the NPV generated by Monte Carlo simulation may be more optimistic or pessimistic compared with the NPV generated by the deterministic model. Consequently, the optimistic values generated by Monte Carlo simulation in this study cannot be generalized. However, when the NPVs generated by the deterministic and stochastic methods were discussed with the 20 experts who participated in this study, it was clear that the NPV found as a result of Monte Carlo simulation was considered by experts to be more "realistic" than the NPV generated by the deterministic approach, because Monte Carlo simulation depends on risk scenarios about the cash flow parameters. It is also clear that the investors' perception of the risk directly affects the probability distributions of the cash flow parameters.

\section{Conclusions}

This paper presents a method that can be used to predict the profitability of hydropower investments by considering the risk factors associated with the energy market.

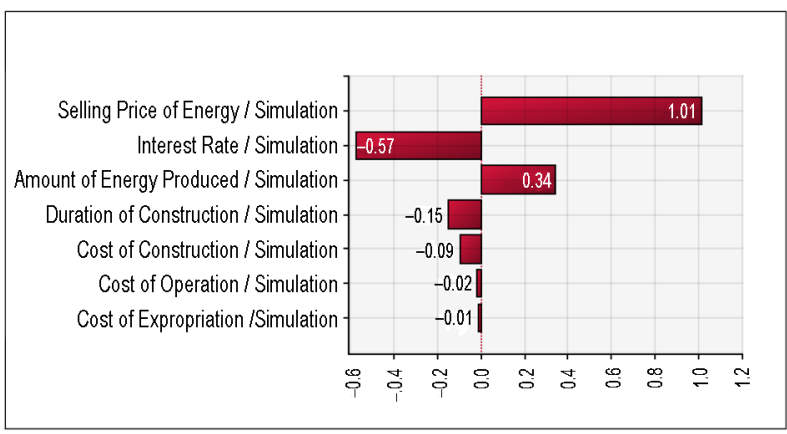

Fig. 3. Tornado graph of cash flow parameters

Using the proposed method, investors should be able to estimate a realistic NPV for hydropower investments. The proposed method was tested in a hydropower project undertaken in Turkey. First, the cash flow parameters of hydropower investments were identified by examining more than 30 feasibility reports. Second, all technical and external risk factors that impact the cash flow parameters in hydropower investments were determined by means of an extensive literature survey. Third, a questionnaire survey was administered to 50 experts to rate the impacts of the risk factors on the cash flow parameters. Fourth, the probability distribution of each cash flow parameter was identified, and the values of the cash flow parameters for the best, most likely, and worst case scenarios were obtained from 20 experts (a subset of the original 50 -expert pool) in a face-to-face meeting. The NPV of the hydropower project was assessed (1) by implementing a deterministic approach that used the most likely estimates of the cash flow parameters, and (2) by performing Monte Carlo simulation that used the probability distributions mentioned above. The results of the deterministic NPV analysis and the Monte Carlo simulation are different. In the hydropower investment used in the case study, Monte Carlo simulation provided a more appealing estimate of the NPV than the one produced by the deterministic approach. Monte Carlo simulation also found that selling price of energy and amount of energy produced are the two most important factors in the cash flow of the hydropower investment considered in the case study. However, the outcome of the analysis may be quite different under different market conditions and government regulations in different countries. Therefore the findings in the case study should not be generalized. The four steps of the proposed method should be duplicated for the evaluation of hydropower investments in other countries.

All experts who took part in the study agree that the proposed stochastic method creates realistic assessments of hydropower investments. The practical contribution of this research is the creation of a method that allows investors to estimate a realistic NPV in hydropower investments. The theoretical contribution of this research is that it provides a comprehensive approach that can be used in different settings in different countries and especially in PPP projects. It is also worth noting that the proposed method can also be used to estimate the profitability of 
other renewable power plant projects such as wind, solar, biomass, and geothermal as well as transportation projects such as toll roads. The proposed model could be expanded to assess other investments.

It should be noted that the selling price of energy is determined in a negotiation between the investor and brokers who sell the energy to corporate customers such as a university campus, or a hospital. Further research on the negotiation process could shed light on the probability distribution of the selling price of energy.

\section{Disclosure statement}

We don't have any competing financial, professional, or personal interests from other parties.

\section{References}

Abedgeno, M. P.; Ogunlana, S. O. 2006. Good project governance for proper risk allocation in public-private partnership in Indonesia, International Journal of Project Management 24: 622-634. https://doi.org/10.1016/j.ijproman.2006.07.010

Akcay, E. C. 2014. Using Monte Carlo simulation and multiagent systems to estimate financial feasibility of HEPP projects tendered on a BOT basis: A case study from Turkey: PhD Thesis. Middle East Technical University.

Al-Bahar, J.; Crandall, K. 1990. Systematic risk management approach for construction projects, Journal of Construction Engineering Management 116: 533-546.

https://doi.org/10.1061/(ASCE)0733-9364(1990)116:3(533)

Beeston, D. 1986. Combining risks in estimating, Construction Management and Economics 4: 75-79. https://doi.org/10.1080/01446198600000005

Bing, L.; Akintoye, A.; Edwards, P. J.; Hardcastle, C. 2005. The allocation of risk in PPP/PFI construction projects in the UK, International Journal of Project Management 23(1): 25-35. https://doi.org/10.1016/j.ijproman.2004.04.006

Blank, L.; Tarquin, A. 2012. Engineering economy. $7^{\text {th }}$ ed. McGraw-Hill, USA.

Chan, A. P. C.; Yeung, J. F. Y.; Yu, C. C. P.; Wang, S. Q.; Ke, Y. 2011. Empirical study of risk assessment and allocation of public-private partnership projects in China, Journal of Management in Engineering 27(3): 136-148. https://doi.org/10.1061/(ASCE)ME.1943-5479.0000049

Flanagan, R.; Norman, G. 1993. Risk management and construction. Victoria: Blackwell Science Pty Ltd., Australia.

Ghorbani, A.; Ravanshadnia, M.; Nobakht, M. B. 2014. A survey of risks in public private partnership highway projects in Iran, in ICCREM 2014@sSmart Construction and Management in the Context of New Technology, ASCE, 482-492.

Ibrahim, A. D.; Price, A. D. F.; Dainty, A. R. J. 2006. The analysis and allocation of risks in public private partnerships in infrastructure projects in Nigeria, Journal of Financial Management of Property and Construction 11(3): 149163. https://doi.org/10.1108/13664380680001086

International Energy Agency (IEA). 2007. Renewables in global energy supply, fact sheet. Paris: OECD/IEA.

James, A. 2013. Three ways to increase hydropower efficiency and revenues. Renewable Energy World.

Jin, X. H.; Zhang, G. 2011. Modelling optimal risk allocation in PPP projects using artificial neural networks, International Journal of Project Management 29: 591-603. https://doi.org/10.1016/j.ijproman.2010.07.011

Karim, N. A. A. 2011. Risk allocation in Public-Private Partnership (PPP) project: A review on risk factors, International
Journal of Sustainable Construction Engineering \& Technology 2(2): 8-16.

Ke, Y.; Wang, S.; Chan, A. P. C.; Lam, P. T. I. 2010. Preferred risk allocation in China's Public Private Partnership (PPP) projects, Journal of Project Management 28: 482-492. https://doi.org/10.1016/j.ijproman.2009.08.007

Lee, R.; Shen, L. Y. 1998. Overview of Chinese government policies to attract BOT investment, Journal of Hong Kong Surveyor 9(1): 48-52.

Li, B.; Akintoye, A. 2008. An overview of public-private partnership, in Public-private partnerships: Managing risks and opportunities, $1-30$.

Lianyu, C.; Tiong, R. L. K. 2005. Minimum feasible tariff model for BOT water supply projects in Malaysia, Construction Management and Economics 23: 255-263. https://doi.org/10.1080/0144619042000287778

Liou, F. M.; Huang, C. P. 2008. Automated approach to negotiations of BOT contracts with the consideration of project risk, Journal of Construction Engineering and Management 134(1): 18-24.

https://doi.org/10.1061/(ASCE)0733-9364(2008)134:1(18)

Liu, J.; Love, P. E.; Smith, J.; Regan, M.; Davis, P. R. 2014. Life cycle critical success factors for public-private partnership infrastructure projects, Journal of Management in Engineering 31(5).

http://dx.doi.org/10.1061/(ASCE)ME.1943-5479.0000307

Liu, T.; Wang, Y.; Wilkinson, S. 2016. Identifying critical factors affecting the effectiveness and efficiency of tendering processes in Public-Private Partnerships (PPPs): A comparative analysis of Australia and China, International Journal of Project Management 34(4): 701-716. https://doi.org/10.1016/j.ijproman.2016.01.004

Malini, E. 1999. Build operate transfer municipal bridge projects in China, Journal of Management in Engineering 15(4): 51-58.

https://doi.org/10.1061/(ASCE)0742-597X(1999)15:4(51)

Medda, F. 2007. A game theory approach for the allocation of risks in transport public private partnerships, International Journal of Project Management 25(3): 213-218. https://doi.org/10.1016/j.ijproman.2006.06.003

$\mathrm{Ng}$, A.; Loosemore, M. 2007. Risk allocation in the private provision of public infrastructure, International Journal of Project Management 25(1): 66-76. https://doi.org/10.1016/j.ijproman.2006.06.005

Ng, T. S.; Xie, J. Z.; Cheung, Y. K.; Jefferies, M. 2007. A simulation model for optimizing the concession period of public private partnerships schemes, International Journal of Project Management 25(8): 791-798. https://doi.org/10.1016/j.ijproman.2007.05.004

Osei-Kyei, R.; Chan, A. 2015. Review of studies on the critical success factors for Public-Private Partnership (PPP) projects from 1990 to 2013, International Journal of Project Management 33(6): 1335-1346. https://doi.org/10.1016/j.ijproman.2015.02.008

Ozdogan, I. D.; Birgonul, M. T. 2000. A decision support framework for project sponsors in the planning stage of BuildOperate-Transfer (BOT) projects, Construction Management and Economics 18(3): 343-353. https://doi.org/10.1080/014461900370708

PMBOK. 2011. Project management body of knowledge. Project Management Institute.

1. Pouliquen, L. Y. 1970. Risk analysis in project appraisal. World Bank Staff Occasional Papers No 11. London: John Hopkins Press Ltd.

Republic of Turkey Ministry of Energy and Natural Resources (RTMENR). 2017. Hydraulics [online], [cited 10 January 2017]. Available from Internet: http://www.enerji.gov.tr/en-US/Pages/Hydraulics. 
Shao, Y.; Yuan, J.; Li, Q. 2016. Identification of the residual value risk factors for road PPP projects in China: Questionnaire survey and analysis, in Proceedings of the $20^{\text {th }}$ International Symposium on Advancement of Construction Management and Real Estate, 2016, 379-389.

Shen, L. N.; Li, H.; Li, Q. M. 2002. Alternative concession model for build operate transfer contract projects, Journal of Construction Engineering and Management 128(4): 326-330. https://doi.org/10.1061/(ASCE)07339364(2002)128:4(326)

Shen, L. Y.; Bao, H. J.; Wu, Y. Z.; Lu, W. S. 2007. Using bargaining game theory for negotiating concession period for BOT-type contract, Journal of Construction Engineering and Management 133(5): 385-392.

https://doi.org/10.1061/(ASCE)0733-9364(2007)133:5(385)

Shen, L. Y.; Platten, A.; Deng, X. 2006. Role of public private partnership to manage risk in public sector project in Hong Kong, International Journal of Project Management 24: 587-594. https://doi.org/10.1016/j.ijproman.2006.07.006

Shen, L. Y.; Wu, Y. Z. 2005. Risk concession model for build operate transfer contract projects, Journal of Construction Engineering and Management 131(2): 211-220.

https://doi.org/10.1061/(ASCE)0733-9364(2005)131:2(211)

Shen, L.; Lee, K. H.; Zhang, Z. 1996. Application of BOT system for infrastructure projects in China, Journal of Construction Engineering and Management 122(4): 319-324. https://doi.org/10.1061/(ASCE)0733-9364(1996)122:4(319)

Singh, L. B.; Kalidindi, S. N. 2006. Traffic revenue risk management through Annuity Model of PPP road projects in India, International Journal of Project Management 24: 605-613. https://doi.org/10.1016/j.ijproman.2006.07.008

Smith, N. J. 1999. Managing risk in construction projects. Blackwell Science.

Song, J.; Song, D.; Zhang, D. 2015. Modeling the concession period and subsidy for BOT waste-to-energy incineration projects, Journal of Construction Engineering and Management 141(10). https://doi.org/10.1061/(ASCE)CO.1943-7862.0001005

Syncopation. 2017. What constitutes a good tornado diagram? [online], [cited 5 January 2017]. Available from Internet: https://www.syncopation.com/blog/what-constitutes-goodtornado-diagram

Tang, L.; Shen, G.; Skitmore M.; Wang, H. 2015. Procurementrelated critical factors for briefing in public-private partnership projects: Case of Hong Kong, Journal of Management in Engineering 31(6).

https://doi.org/10.1061/(ASCE)ME.1943-5479.0000352
TCA. 2016. Turkish contractors association [online], [cited 7 Decemeber 2016]. Available from Internet:

http://www.tmb.org.tr

Wang, S. Q.; Tiong, R. L. K.; Ting, S. K.; Ashley, D. 2000. Evaluation and management of foreign exchange and revenue risks in China's BOT projects, Construction Management and Economics 18: 197-207. https://doi.org/10.1080/014461900370825

Wibowo, A.; Mohamed, S. 2010. Risk criticality and allocation in privatised water supply projects in Indonesia, International Journal of Project Management 28: 504-513. https://doi.org/10.1016/j.ijproman.2009.08.003

Xenidis, Y.; Angelides, D. 2005. The financial risks in buildoperate-transfer projects, Construction Management and Economics 23(4): 431-441.

https://doi.org/10.1080/01446190500041552

Xing,W.; Wu, F. F. 2001. A game-theoretical model of private power production, International Journal of Electrical Power \& Energy Systems 23(3): 213-218. https://doi.org/10.1016/S0142-0615(00)00059-4

Xu, Y.; Hu, C.; Chan, A. P. C. 2009. Risk factors for running Public Private Partnerships (PPP) - An empirical comparison between government and private sector, in International Conference on Management and Service Science (MASS'09), 2009, Wuhan, China.

Ye, B. S.; Tiong, R. L. K. 2000. NPV-at-risk method in infrastructure project investment evaluation, Journal of Construction Engineering and Management 126(3): 227-233. https://doi.org/10.1061/(ASCE)0733-9364(2000)126:3(227)

Yuan, J. F.; Deng, X. P.; Li, Q. M. 2008. Critical risks identification of Public Private Partnerships in China and the analysis on questionnaire survey, in $4^{\text {th }}$ International Conference on Wireless Communications, Networking and Mobile Computing (WiCOM'08), 2008, Dalian, China. https://doi.org/10.1109/wicom.2008.2453

Zayed, T. M.; Chang, L. M. 2002. Prototype model for buildoperate-transfer risk assessment, Journal of Management in Engineering 18(1): 7-16.

https://doi.org/10.1061/(ASCE)0742-597X(2002)18:1(7)

Zhang, X. 2005. Paving the way for public-private partnerships in infrastructure development, Journal of Construction Engineering and Management 131(1): 71-80. h ttps://doi.org/10.1061/(ASCE)0733-9364(2005)131:1(71)

Zhang, X. Q.; Abourizk, S. M. 2006. Determining a reasonable concession period for private sector provision of public works and services, Canadian Journal of Civil Engineering 33(5): 622-631. https://doi.org/10.1139/106-010

Emre Caner AKCAY. Dr Emre Caner Akcay is currently postdoctoral visiting researcher and part-time instructor of Civil, Architectural and Environmental Engineering at Illinois Institute of Technology. Prior to joining IIT, Dr Emre Caner Akcay was a part-time instructor at Middle East Technical University. He received his PhD, MS and BS degrees in 2014, 2010 and 2008 at Middle East Technical University. His research interests include sustainability, information technologies in construction, project planning and design, contracting and project delivery systems.

Irem DIKMEN. Professor and lecturer in the Construction Management and Engineering Division of the Civil Engineering Department in the Middle East Technical University. Her primary research interests include risk management, knowledge management, strategic management of construction companies and use of IT to improve the construction value chain. She also conducts extensive research in the area of risk management of BOT projects in Turkey. In addition to her research activities, she gives continuing education seminars and consultancy services to construction professionals about international business development and construction risk management.

M. Talat BIRGONUL. Professor and lecturer in the Construction Management and Engineering Division of the Civil Engineering Department in the Middle East Technical University. His primary research interests include engineering economy, international construction, construction planning, macroeconomic aspects of the construction industry and claim management. Apart from his academic activities, he acts as an expert witness in Turkish courts and Arbitral Tribunals and gives a claim management consultancy 
service to leading construction companies. Currently, he is acting as the director of Construction Management and Engineering Division of the Civil Engineering Department in the Middle East Technical University.

David ARDITI. Dr David Arditi is currently Professor of Civil and Architectural Engineering at Illinois Institute of Technology. $\mathrm{He}$ is the founder and Director of the Construction Engineering and Management Program. Professor Arditi's area of expertise covers all aspects of construction project management, engineering and support. In his 40-year academic career, he conducted several funded research projects sponsored by federal and state agencies. He supervised the research work of a large number of PhD and MS students from diverse countries. Many of his former PhD students serve as professors in their respective countries, while many of his former MS students occupy respectable positions in industry all over the world. Dr Arditi and his research associates have published over 300 research papers in refereed national and international journals and in peer reviewed conference proceedings. He is currently serving on the editorial board of nine journals in the field of construction project management, and regularly reviews research proposals, papers and books for several research agencies and publishers. Dr Arditi is an active member of several professional societies including CMAA, ASCE, AACE, and PMI. He has served over the years in many international, national and regional committees and was on several organizing committees of national and international conferences. He delivered several invited lectures and keynote lectures at different venues. He is also the recipient of multiple awards, including being elected to the College of Fellows of CMAA in 2013, and being elected Professor of the Year by CAEE students in 2016. 